University of Montana

ScholarWorks at University of Montana

Teaching and Learning Faculty Publications

2003

\title{
Ecology Education When no Child is Left Behind
}

\author{
Lisa Blank \\ University of Montana - Missoula, lisa.blank@umontana.edu \\ Carol Brewer \\ Okhee Lee \\ Aurolyn Luykx \\ Susan Barker
}

See next page for additional authors

Follow this and additional works at: https://scholarworks.umt.edu/cis_pubs

Part of the Curriculum and Instruction Commons

Let us know how access to this document benefits you.

\section{Recommended Citation}

Blank, Lisa; Brewer, Carol; Lee, Okhee; Luykx, Aurolyn; Barker, Susan; Slingsby, David; Hollweg, Karen; Comfort, Kathy; and Bybee, Rodger W., "Ecology Education When no Child is Left Behind" (2003). Teaching and Learning Faculty Publications. 3.

https://scholarworks.umt.edu/cis_pubs/3

This Article is brought to you for free and open access by the Teaching and Learning at ScholarWorks at University of Montana. It has been accepted for inclusion in Teaching and Learning Faculty Publications by an authorized administrator of ScholarWorks at University of Montana. For more information, please contact scholarworks@mso.umt.edu. 


\section{Authors}

Lisa Blank, Carol Brewer, Okhee Lee, Aurolyn Luykx, Susan Barker, David Slingsby, Karen Hollweg, Kathy Comfort, and Rodger W. Bybee 


\section{Ecology education when no child is left behind}

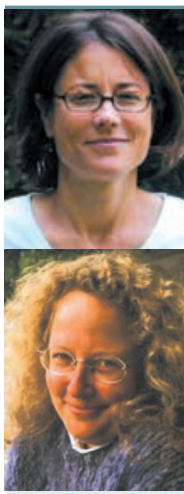

Lisa Blank ${ }^{1}$ and Carol Brewer ${ }^{2}$

${ }^{1}$ Dept of Curriculum and Instruction,

University of Montana, MT, USA

${ }^{2}$ Dept of Biological Sciences, University of

Montana, MT, USA

When President Bush signed the No Child Left Behind (NCLB) Act of 2001, he propelled public education to the top of America's domestic agenda. This legislation changes the federal role in $\mathrm{K}-12$ education by holding schools accountable for the annual progress of their students. According to the US Department of Education (USDE 2002), NCLB focuses on four key elements of education reform: stronger school-by-school accountability for the level of student achievement; increased flexibility and control over how federal education funds are spent at the local level; expanded options for parents to choose where their children are educated; and incentives to use teaching methods and curricula that have been "proven scientifically" to be effective.

Few of us would leap to criticize a national policy focused on improving teaching and ensuring all children receive a satisfactory education. Specifically, every child, regardless of socioeconomic status, gender, or race, will make "adequate yearly progress toward academic proficiency". But as is often the case, the devil is in the details. What is adequate, how will proficiency be defined, and to what extent will the tests measuring it drive what and how children are taught? Where does ecological literacy fit, if at all, as we focus on education accountability?

On the 2000 National Assessment of Educational Progress (NAEP) science test, $82 \%$ of high school seniors performed below proficiency levels. The challenge is that "America's schools are not producing the science excellence required for global economic leadership and security in the 21st century" (USDE 2002). NCLB will "ensure schools use research-based methods to teach science and measure results, and to establish partnerships with universities to ensure that knowledgeable teachers deliver the best instruction in their field, and every school (and teacher) will be accountable" (USDE, 2002).

NCLB mandates that teaching be transformed into an evidence-based discipline and practice. Funding is to be directed so that "only the best ideas with proven results are introduced to the classroom" (USDE, 2002). This means that all subjects, including science, must be taught based on empirical studies (experimental or quasi-experimental designs) with systematic and objective procedures that produce valid and reliable datasets. Results from these studies should be convergent and broadly generalizable to students other than the ones studied (www.NoChildLeftBehind.gov). In our judgment, few such rigidly defined datasets exist for science education, let alone for teaching ecology at any educational level. Furthermore, setting rigidly defined, controlled experiments as the standard for educational research is no more likely to lead to uniformly better decisions about science curricula and pedagogy than to broad generalizations about ecological phenomena.

While chief education administrators may be sold on applying the methods of clinical drug trials to educational research, the research community remains skeptical (Feuer et al. 2002). Kilpatrick (2001) cautioned that, unlike a controlled clinical drug trial, inherent difficulties in controlling for factors such as the attitude and competence of a teacher, the topic, the context of instruction, and individual student variation limit inferences that can be made from the results. Furthermore, people grow and change over time, and the way that they come to understand abstract concepts and ideas is powerfully influenced by cultural traditions and ways of knowing, as well as by the context in which they live (NRC 2002). Consequently, the approaches used by educational researchers are markedly different from those of clinical studies that more readily lend themselves to randomized trials, controlled conditions, and repeated measures.

Beginning in 2007, all states must measure students' progress in science at least once in three grade spans each year, and all children must leave the K-12 academic pipeline with proficient science skills. Test scores will be disaggregated to reduce the temptation of using average values to hide the progress of failing students. If students do not make "adequate yearly progress" (defined on a state-by-state basis), schools face a number of sanctions after year three. These include giving parents the opportunity to choose another school, after-school tutoring services, extending the school year or day, hiring an outside expert, changing the curriculum, replacing staff, restructuring the school, and possibly takeover of the school by the state or a private management team.

What is wrong with holding schools accountable for meeting the needs of all students? Nothing. In fact, we applaud efforts to recognize the discrepancy in learning opportunities for large portions of our $\mathrm{K}-12$ student population. What concerns us is that the high-stakes implications of these tests will inevitably result in teachers using them as the central organizer for their curriculum. Already in our region, school teachers have deplored the marginalization of science. "I don't teach much science lately because the administration is pushing us to focus on reading and writing skills, and they have made it very clear that we have to get our test scores up", lamented a third grade teacher. On a national level, the story is the 
same; the tests have begun to drive the curriculum. For example, consider Texas, an early adopter of high-stakes testing. In a study of the impact of the Texas Assessment of Academic Skills (TASS), Haney (2000) reports that Texas schools are already devoting considerable amounts of time and energy to preparing students for the TASS.

But what do the tests measure? What knowledge is considered to be of greatest worth? Will important ecological concepts be included? Students' understanding of complex ecological interactions is not easily measured on multiple-choice exams focused on measuring proficiency with discrete concepts and processes. A study by the Rand Corporation (Grissmer et al. 2000) found that high-stakes tests primarily focus on lower-order thinking skills; for example, memorization and factual recall. In an item analysis we conducted on the 43 multiple-choice questions about science on the 2002 Iowa Basics Skills standardized test for seventh graders, only three questions loosely related to ecological concepts and knowledge. Nineteen questions focused on process skills and understanding of experimental methodology (independent/dependent variables, and so on), while 15 questions tested physical/earth science content. Is this example standardized test the proverbial canary in the coal mine for ecology education in the $\mathrm{K}-12$ arena? Ecological content knowledge is not well represented on this test. Even more troubling, however, is that the exam generally reads like a middle school version of Trivial Pursuit. Is this the future of science education to which we are commending our nation's children?

For the past 20 years, professional ecologists have argued that it is crucial for children to learn to apply ecological concepts in the real world, and to use inquiry skills and ecological knowledge to investigate the local environment (eg Feinsinger et al. 1997). Congruent with the views of ecologists, the US Department of Labor Secretary's Commission on Achieving Necessary Skills (USDL 1991) recommended that "teaching should be offered in context, that is, students should learn content while solving realistic problems. 'Learning in order to know' should not be separated from 'learning in order to do'." Where will NCLB position "learning in context", particularly as it relates to the future of ecological education in pre-college classrooms? Perhaps the greatest potential value of NCLB in this regard will be to engage professional ecologists in the national conversation and research addressing how children learn about the world around them.

King and Kitchener (1994) argued that one of the most important responsibilities educators have is helping students learn to make defensible judgments about vexing problems. To do this, we need to understand how people learn, and to transfer that understanding into classroom practice. Research is needed on the effectiveness of teaching practices focused on "learning by doing" in outdoor laboratories and on how students develop scientific ways of thinking. Ecologists must work with education colleagues to help set the agenda for ecological education. Moreover, we need to participate in research addressing methods related to pedagogy and epistemology of developing ecological literacy, how people learn ecology and develop ecological thinking, and the related implications for training teachers. Importantly, we have to agree on the criteria and the type of evidence we need and will accept in order to judge the impact of science education approaches and proficiency in ecological understanding. Federal policy makers need to know that these studies, and the evidence they produce, may be very different from clinical studies to determine the efficacy of a new drug.

\section{References}

Feinsinger P, Margutti L, and Oviedo R. 1997. Schoolyard and nature trails: ecology education outside the university. Trends Ecol Evol 12: 115-20.

Feuer M, Towne L, and Shavelson RJ. 2002. Scientific culture and educational research. Educ Res 31: 4-14.

Grissmer DW, Flanagan A, Kawata J, and Williamson S. 2000. Improving student achievement: what state NAEP test scores tell us. Santa Monica, CA: Rand Corporation.

Haney W. 2000. The Texas Miracle in Education. Education Policy Analysis Archives: Center for Education, Research, Analysis, and Innovation. http://epaa.asu.edu/epaa/v8n41.

Kilpatrick J. 2001. Where's the evidence? J Res Math Educ 32 421-27.

King PM and Kitchener KS. 1994. Developing reflective judgment: understanding and promoting intellectual growth and critical thinking in adolescents and adults. San Francisco, CA: JosseyBass Publishers.

NRC (National Research Council). 2002. Scientific research in education. Washington, DC: National Academies Press.

USDL (US Department of Labor). 1991. Secretary's commission on achieving necessary skills. Washington, DC: United States Government Printing Office.

USDE (US Department of Education). 2002. No Child Left Behind Facts sheets. www.nclb.gov/start/facts/science.html.

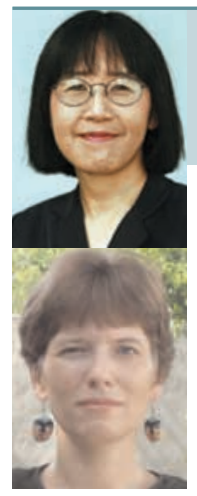

Okhee Lee and Aurolyn Luykx Dept of Teaching and Learning, University of Miami, FL, USA

While generally agreeing with the key points addressed by Blank and Brewer, we would extend and elaborate them with regard to students from non-mainstream backgrounds, who are disproportionately affected by recent accountability measures. We will address two issues. First, by linking science content to students' prior knowledge, ecological education can serve as a means to teach other core subject areas, especially to non-mainstream students. Second, if high-stakes assessments are to adequately measure these students' knowledge and abilities, they must be designed and imple- 
mented to minimize distortion arising from cultural and linguistic factors.

Accountability in science education operates under different conditions than other core subjects. In the elementary grades, science is emphasized in tests far less than reading, writing, and mathematics (Hewson et al. 2001; Spillane et al. 2001), and when science is not part of statewide assessments it is taught to a minimal degree. As NCLB will require science assessment starting in 2007, more states will be including science in their accountability measures. While this may be good news for school science, it has both positive and negative implications for non-mainstream students, who are already at a disadvantage in high-stakes testing situations.

In schools serving high numbers of students who are economically disadvantaged and/or learning English as a new language, basic skills like literacy and numeracy are emphasized at the expense of other subject areas, including science. Yet, science - particularly hands-on and inquiry-based instruction - can be a vehicle to teach oral and written English and mathematics, as well as problem-solving and critical thinking. Unfortunately, school science supplies are not always available, particularly in inner-city schools with limited funding and resources. Students attending these schools (most of whom come from immigrant and/or low-income backgrounds) are the ones who most need hands-on and inquiry-based science instruction, for a number of reasons: (1) hands-on activities are less dependent on formal mastery of the language of instruction, thus reducing the linguistic burden on English language learners (ELLs); (2) collaborative, small-group work provides structured opportunities for developing English proficiency in the context of communication about science knowledge; and (3) hands-on activities for exploring natural phenomena make science concepts more accessible to students with limited science experience than do approaches based on decontextualized textbook knowledge.

In traditional science courses such as physics or chemistry, mainstream students often enter with an advantage over their non-mainstream peers, due to their prior exposure to scientific knowledge and discourse. In contrast, ecological education provides a context for the construction of scientific knowledge in which non-mainstream students may participate on a more equal footing, since all students have cultural and linguistic knowledge related to the ecologies of their home communities. Additionally, students' ecological knowledge of their home environments can provide rich opportunities to share and develop collective reasoning and understanding about ecological issues from a multicultural and global perspective.

Herein lies the irony. Science education in general, and ecological education in particular, can provide rich learning environments across subject areas for students from nonmainstream backgrounds. However, these students are less likely to be exposed to such instruction until they develop English proficiency or basic skills in literacy and numeracy.

Even when these students receive quality science instruc- tion, standard assessments may fail to adequately measure their knowledge and abilities (McNeil 2000). Complex issues abound in high-stakes assessments and testing, such as whom to include, how best to accommodate students with special needs, and how to assess content knowledge separately from English proficiency or general literacy (RuizPrimo and Shavelson 1996; Shepard et al. 1998).

An obvious pitfall involves testing students in a language that they are still in the process of learning (SolanoFlores and Trumbull 2003). Anything short of bilingual test administration is likely to underestimate their knowledge and abilities, yet such practice is virtually unheard-of in large-scale assessments. Even when testing accommodations (eg provision of bilingual dictionaries, longer testing time, and translation of test questions) are required by state laws, school personnel are often unaware of accommodation mandates or are unwilling to dedicate the resources necessary to comply with them. As more states adopt "English-only" policies and hold ELLs (and the schools serving them) accountable for their test scores, these students simply do not have equitable opportunities to demonstrate what they know and are capable of doing.

Ultimately, what is needed is not only ecological education, but an ecological or systems approach to science instruction and assessment - in other words, one that takes into account the relationships between students' academic performance, cultural backgrounds, school language policies, teachers' science knowledge, instructional practices, and institutional features. The complex relationships between these factors cannot be deciphered solely through experimental or quasi-experimental means. Nor can student outcomes be accurately measured solely by high-stakes assessments as currently conceived and implemented. Reductive "accountability" policies in education not only further marginalize traditionally underserved students; they also ignore fundamental ecological principles by failing to recognize the multifaceted, systemic nature of student learning and of the context in which it occurs.

\section{References}

Hewson PW, Kahle JB, Scantlebury K, and Davies D. 2001. Equitable science education in urban middle schools: Do reform efforts make a difference? J Res Science Teach 38: 1130-44.

McNeil LM. 2000. Creating new inequalities: Contradictions of reform. Phi Delta Kappan 81: 729-34.

Ruiz-Primo MA and Shavelson RJ. 1996. Rhetoric and reality in science performance assessments: an update. J Res Science Teach 33: 1045-63.

Shepard L, Taylor G, and Betebenner D. 1998. Inclusion of limitedEnglish-proficient students in Rhode Island's grade 4 mathematics performance assessment. CSE Technical Report 486. Los Angeles, CA: University of California, National Center for Research on Evaluation, Standards, and Student Testing.

Solano-Flores G and Trumbull E. 2003. Examining language in context: the need for new research and practice paradigms in the testing of English-language learners. Educ Res 32:3-13.

Spillane JP, Diamond JB, Walker LJ, et al. 2001. Urban school leadership for elementary science instruction: Identifying and activating resources in an undervalued school subject. J Res Science Teach 38: 918-40 


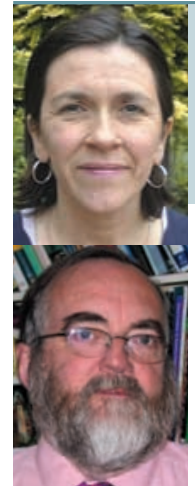

Susan Barker ${ }^{1}$ and David Slingsby ${ }^{2}$

${ }^{1}$ Institute of Education, University of

Warwick,UK

${ }^{2}$ British Ecological Society, Wakefield, UK

NCLB and its implications, as discussed by Blank and Brewer, are only too familiar to us in England and Wales, where a similar process has been underway since the 1980s. The British educational system continues to serve the elite well, yet disgracefully low levels of literacy and numeracy have been tolerated for too long among disadvantaged groups.

Our education system has been transformed into a sanitized, assessment-led process; we follow a national science curriculum, have a National Science Scheme of Work, conduct national standardized science tests at ages 7, 11, and 14, and then publish school performance league tables based on pupils' grades. It seems that the whole notion of education being creative and opportunistic has been lost through the very bureaucracy that was intended to raise standards. The implementation of initiative after initiative, particularly to raise standards in literacy and numeracy, has been at the expense of a narrowing of the curriculum with the marginalization of subjects such as music and drama. Specialized areas of science such as ecology are in danger of being lost in a plethora of scientific processes, ideas, and evidence. Paradoxically, this comes at a time when sustainable development and citizenship have become important politically, and when there is global demand for a scientifically literate workforce. We agree that we now know whether our children are being left behind and where they are in a general academic sense, but this has been at the expense of an overemphasis on teaching what is most easily tested; for example, knowledge rather than skills and application.

Ecology does remain within the Science National Curriculum, but the inclusion of biological fieldwork, which makes it come alive and which has long been a feature of UK biological education, is currently in serious decline. A national science curriculum, which sets out what should be every citizen's minimum educational entitlement, would not be such a bad thing if it went beyond literacy and numeracy. We believe that every pupil should have a statutory entitlement to the kind of out-of-classroom activity that opens students' eyes to the natural beauty of the environment, allows them to understand its complexity and helps them to appreciate the need to behave in a way that will protect it.

One of the advantages of creating a national curriculum is that it provides a framework in which current provisions can be reappraised. When the first Science National Curriculum was launched in England and Wales in 1989, it was based on an amalgam of existing provisions, including elements of traditional academic science in the form of chemistry, physics, and biology. What it did do, however, was to make science a core subject for all pupils from 5 to 16 years; there was the need to prepare the academically able ones for further study of science and a contrasting requirement to cater to the needs of the ordinary citizen. The outcome of this was a science curriculum that appeared as a catalogue of discrete ideas, lacking coherence and relevance, which failed to sustain and develop a sense of wonder and curiosity about the natural world (Millar and Osborne 1998). Science teachers felt that the curriculum was insufficiently flexible to allow them to meet the needs of all their pupils and provide them with an enjoyable scientific education (Jenkins 2000). Many of these issues have been thought through, leading to the development of the 21st Century Science project (www.21stcenturyscience.org). Three courses starting in September 2003 for 14- to 16-yearolds will offer greater flexibility and genuine choice to cope with the diversity of students' interests and aspirations.

So what can organizations like the British Ecological Society and the Ecological Society of America do? Curriculum changes offer opportunities as much as they do threats. We need to think carefully about why and how we teach the carbon cycle. We no longer teach animal classification phylum by phylum, but how should we introduce pupils to the fascination of biodiversity in a way that is neither academically too heavy nor too superficial? What stays with young people after they have forgotten the scientific facts we taught them may well be the teacher's enthusiasm, a lifelong interest in the world around them, and an appreciation of the value of the environment.

If no child is to be left behind, we need to support teachers. We need to continue the programs that produce innovative creative teaching material, develop our educational websites for teachers and pupils alike, and provide training opportunities for teachers in ecology. We must also promote ecology whenever the opportunity arises, maintaining a high profile at a time when other areas of biology such as genomics are perceived to be more valuable.

In a world obsessed by national tests and examinations, progress will come through improved assessment techniques. The recently launched Salters-Nuffield Advanced Biology project (www.advancedbiology.org), aimed at 16to 18-year-old high school students, includes a substantial ecological component. Its activity-based and thematic approach is quite radical, and emphasis is placed on understanding, application, critical thinking, and social and ethical context as much as on factual content. A key part of the process is the development of a style of examination that assesses much more than mere factual recall and which rewards good teaching. It does conform to UK government guidelines for biology at this level, but more importantly, what pupils will achieve is meaningful and valued; they will not be left behind.

\section{References}

Jenkins E. 2002. The impact of the national curriculum on secondary school science teaching in England and Wales. Int J Sci Educ 22: 325-36.

Millar R and Osborne J. 1998. Beyond 2000: science education for the future. London, UK: Kings College. 


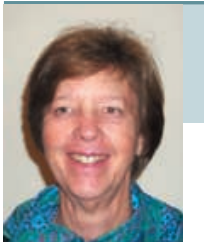

\section{Karen Hollweg}

Educator, Boulder, CO, USA

I bristle when I read that NCLB has "propelled public education to the top of America's domestic agenda". Education has been at or near the top of the list of important issues for the public and politicians for years - NCLB did not cause that to happen. Indeed, it was President George HW Bush who convened the first National Education Summit in 1989, bringing together state governors and federal officials to address education. Their discussions and commitment led to support for national education standards and to a multiyear accountability process that moved states forward in achieving the National Education Goals. Some have called the past 13 or 14 years the longest sustained effort to improve education in our nation's history - and that effort has had bipartisan public and political support.

NCLB's goal of improving education for all children is not new. That has been the aim of the country's education reform efforts for over a decade. Since the publication of Science for All Americans (AAAS 1989) and the National Science Education Standards (NRC 1996), and through many initiatives aimed at implementing the vision set forth in those documents, states and local districts across the country have been working hard to provide quality science education for all students. They have been working to improve teaching, assessment, student learning, professional development, and system supports needed to provide all students with the opportunity to attain high levels of scientific literacy. It is therefore not surprising to find broad support for the goal of improving education for all children, as described in NCLB.

Many schools in America remain poorly funded. Children who live in poverty, get less parental support and encouragement to do well in school, and have poorly-prepared teachers and deficient instructional materials and facilities, cannot be expected to "make adequate yearly progress towards proficiency" in reading, mathematics, or science. Biddle (1997) did extensive analyses of datasets from large-scale international and nationwide tests (SIMS, TIMSS, and NAEP) and found that, for example, the US has greater disparities in school funding and higher levels of child poverty than other developed countries participating in recent international studies, and that these differences are strongly correlated with the differences in student achievement.

Less than $10 \%$ of all funds invested in public education come from the federal government; nearly half come from state revenues. States and districts have made some progress in elevating teachers' salaries and equalizing resources among rich and poor school districts. In addition, federal funding continues to supplement local resources, especially in districts where large numbers of students live in poverty. Changing the way federal funds are spent at the local level (as NCLB proposes to do) is a very small piece of the puzzle. The number of tests and rewards or sanctions based on test results, as specified in NCLB, is not where I would focus attention.

Teachers are key when it comes to improving student learning; through professional development (PD), teachers' knowledge of science and ecology, skills and abilities can be enhanced. The education literature includes an increasing number of studies describing PD needs and connections between PD, teaching practices, and increases in student learning (Supovitz and Turner 2000; Scantlebury et al. 2001; Weiss et al. 2003). Continuing education for teachers is more like exercise that one needs regularly to stay fit, rather than an inoculation that lasts for life. Studies show that sustained multi-year PD with follow-up support can lead teachers to implement more progressive instructional strategies, as advocated in the National Standards, but that they return to more traditional methods when follow-up support is lacking and testing pressures are felt (Kannapel et al. 2001).

As a society, we must support our educators in enhancing their skills and abilities on an ongoing basis, using research findings to inform the design of the learning opportunities offered. Where NSF funds have been invested in welldesigned PD, teachers have been able to improve their classroom practices. However, these are expensive investments, and to date they have only been available to a fraction of our 2.7 million $\mathrm{K}-12$ teachers. A much larger investment is needed if all teachers are to have access to quality PD, all children are to be taught by well-prepared teachers, and national data on student achievement is to show proficiency.

For almost 15 years we have mustered the will to pursue the challenge of improving science education for all children. Now we must muster the political will to take the next steps, based on what we have learned so far. So, what can ecologists do?

- Participate and encourage colleagues and neighbors to participate in $\mathrm{K}-12$ school funding and public policy decisions, especially decisions in your state and area.

- Get involved with educators in professional development programs funded through the Mathematics and Science Partnerships (Title II, Part B of NCLB) administered by your state's Department of Education and USDE, and through several programs in NSF's Education and Human Resources Directorate. Make sure that ecological content and scientists' ways of knowing are well represented.

- Learn more about progressive science education and what research has to say about how people learn. Three National Research Council documents that may be useful, because they summarize current thinking among educators and researchers regarding the improvement of education, are included in the reference list (NRC 2002; Hollweg and Hill 2003; Bransford et al. 1999).

No matter what you choose to do, remain determined and stay the course. Improving science education for all children will be achieved only by sustained effort and sufficient funding - not by quick fixes. 
References

AAAS (American Association for the Advancement of Science). 1989. Science for all Americans: a Project 2061 report on literacy goals in science, mathematics, and technology. Washington, DC: AAAS.

Biddle BJ. 1997. Foolish, dangerous nonsense, and real correlates of state differences in achievement. Phi Delta Kappan 79: 8-13.

Bransford JD, Brown AL, and Cocking R (Eds). 1999. How people learn: brain, mind, experience, and school. Washington, DC: National Academy Press.

Hollweg KS and Hill D. 2003. What is the influence of the National Science Education Standards? Reviewing the evidence, a workshop summary. Washington, DC: The National Academies Press.

Kannapel PJ, Aagaard L, Coe P, and Reeves CA. 2001. The impact of standards and accountability on teaching and learning in Kentucky. In: Fuhrman, SH (Ed). From the capitol to the classroom: standards-based reform in the states. The one hundredth yearbook of the National Society for the Study of Education Pt 2. Chicago, IL: University of Chicago Press. p 242-62.

National Research Council. 1996. The National Science Education Standards. Washington, DC: National Academy Press.

National Research Council. 2002. Investigating the influence of standards: a framework for research in mathematics, science, and technology education. Washington, DC: National Academy Press.

Scantlebury K, Boone W, Kahle JB, and Fraser BJ. 2001. Design, validation, and use of an evaluation instrument for monitoring systemic reform. J Res Science Teach 38: 646-62.

Supovitz JA and Turner HM. 2000. The effects of professional development on science teaching practices and classroom culture. J Res Science Teach 37: 963-80.

Weiss IR, Pasley JD, Smith PS, et al. 2003. Looking inside the classroom: a study of $\mathrm{K}-12$ mathematics and science education in the United States. www.horizon-research.com/insidetheclassroom. Viewed 10 June 2003.

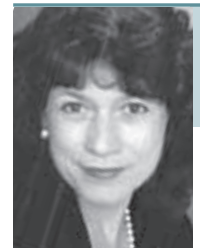

\section{Kathy Comfort}

WestEd, San Francisco, CA, USA

The release of the National Research Council's National Science Education Standards (NSES) in 1996, as well as the AAAS' Project 2061 Benchmarks for Science Literacy (BSL) in 1993, represented the national consensus of the science education community about what was important and meaningful for all students to know, do, and understand in science.

In response, many states, districts, and schools quickly began to try to reform the quality of their science programs. They expected these efforts to result in improved learning, which in turn would lead to high student achievement in science. However, they were faced with a problem - how would they know if their students were learning the content recommended by national science standards? Educators clearly needed a valid and reliable standards-based assessment to measure student progress towards science literacy.

As the primary feedback mechanism in the educational system, assessment communicates the goals that students, teachers, schools, and districts are expected to achieve (NRC 1996). Research shows that students learn what they are taught and that teachers teach what they are held accountable for (Shavelson et al. 1990). To achieve desired educational reform, assessments must be aligned to the content recommendations of the national standards. Alignment ensures that tests match the learning goals embodied in the standards, and thus enables the public to determine student progress toward them (Webb 1997).

In response to the clear need for standards-based science assessment, the National Science Foundation funded the California Systemic Initiatives Assessment Collaborative (CSIAC) in 1996. This built on current research in science assessment development and scoring (Comfort 1995; Klein et al. unpublished). The resulting assessments are aligned to the content recommendations of the NSES and the BSL. They consist of a balance of measures enhanced multiple-choice questions, open-ended questions, constructed response investigations, and hands-on performance tasks - that tap into different aspects of knowledge (Baxter and Shavelson 1994), and they also inform instruction and help guide professional development. In 1999, since CSIAC was by then being used in many states outside California, its name was changed to the Partnership for the Assessment of Standards-based Science (PASS).

On the heels of current science reform efforts, the NCLB legislation specifies that by 2007-08, states must administer a science assessment at least once during grades 3-5, grades 6-9, and grades 10-12. Among other requirements, this science assessment should preferably be criterion referenced, and must be aligned to state content standards and student academic achievement standards. Furthermore, the assessment must provide evidence of technical quality and be consistent with professional testing standards.

In keeping with NCLB, PASS testing measures student achievement across the content areas of the national standards: inquiry, life science, physical science, earth and space science, science and technology, and the history and nature of science. PASS uses multiple measures, designed to assess higher order thinking skills as well as more domain-specific knowledge, to get a more complete picture of what students know and can do. PASS is also closely aligned to the science content standards of all states that use national standards as a foundation for their own.

PASS contains items that measure student understanding of ecological concepts. For example, in the 10th grade performance task students are asked to help investigate the effects of a chemical spill on the organisms in a lake. They use hands-on materials to investigate the substances spilled, record data and observations, organize their data, use their data to draw conclusions and report results, and apply what they learned to explain what might happen to the organisms in the immediate future and over a longer period. National standards aligned to this task include life science, the interdependence of life (NSES), the living environment-interdependence of life (BSL), and the ability to carry out scientific inquiry (NSES).

Examples of other PASS items addressing ecological con- 
cepts include constructed response investigations focusing on life cycles (grade 5) and on the relationship between organisms and their environment (grades 5 and 8). Additionally, several enhanced multiple-choice questions at all grade levels address ecology.

While most large-scale standardized tests are reported to drive curriculum, PASS is designed to help support instruction by providing useful, practical information to teachers about their students' progress. Because it emphasizes the use of data, teachers can learn where there are gaps in their instruction and help students improve in those areas (NRC, unpublished).

This kind of assessment is crucial to the eventual success of NCLB. If teachers believe that the only way to meet the annual progress goals of NCLB is to "teach to the test", using standardized multiple-choice science tests, then yearly gains may not mean improvement in knowledge or understanding of science, but only improvement in memorization and test-taking skills.

Teachers are central to keeping curriculum, instruction, and assessment closely linked. Current research maintains that improving teachers' assessment skills stimulates thinking about the curriculum, and about how different instructional approaches can support student learning (Shingold et al. 1995). When teachers are given the opportunity to learn how to use assessment data in conjunction with their instruction, they have greater knowledge of what their students can do (Shepard 1995), and their behavior differs from those of teachers without such information (Roberts 1996).

The requirements of NCLB may be a positive step for science education reform, but only if schools select appropriate assessments, and if results are linked effectively to classroom instruction, assessment, and teacher practice. Furthermore, the assessments must provide the tools needed to use the resulting data to improve both instruction and student achievement.

\section{References}

Baxter GP and Shavelson RJ. 1994. Science performance assessments: benchmarks and surrogates. Int J Educ Res 21: 279-98.

Comfort KB and Michelson P. 1995. A sampler of science assessment. Sacramento: California Department of Education.

National Research Council. 1996. National Science Education Standards. Washington, DC: National Academy Press.

Roberts LLC. 1996. Methods of evaluation for Public Understanding Program. ( $\mathrm{PhD}$ dissertation). Berkeley, CA: University of California.

Shavelson RJ, Carey NB, and Webb NM. 1990. Indicators of science achievement: options for a powerful policy instrument. Phi Delta Kappan 71: 692-97.

Shepard LA. 1995. Using assessment to improve learning. Educ Leadership 52: 38-43.

Sheingold K, Heller J, and Paulukonis S. 1995. Actively seeking evidence: teacher change through assessment development. Princeton, NJ: Center for Performance Assessment, Educational Testing Services.

Webb N. 1997. Determining alignment of expectations and assessments in mathematics and science education. Madison, WI: National Center for Improving Science Education.

Ecology education is on the verge of something new. In the

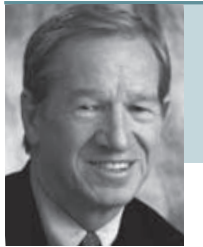

\section{Rodger W. Bybee \\ Biological Sciences Curriculum Study, Colorado Springs, CO, USA}

past decade, several publications have brought ecology to a level of national prominence and acceptance long recognized by ecologists. National Science Board (NSB) reports such as Environmental Science and Engineering for the 21st Century (NSB 2000) and Complex Environmental Systems (NSB 2003), the work of non-governmental organizations such as the National Council for Science and the Environment (NCSE 2000, 2003), and the writings of prominent individuals such as Edward O Wilson (2002) and Lester Brown (2001) all argue for perspectives that will profoundly influence ecology education.

Characteristics of a new ecology education include interdisciplinary and multidisciplinary approaches; recognition of the inherent complexity and nonlinearity of most environmental systems; larger temporal and physical scales; human components such as economics and politics; and technology as an essential aspect of research and the means to address challenges for science education. These potential changes in ecology education must be contrasted with the NCLB Act.

Along with many in the education community, I find NCLB paradoxical at best and detrimental at worst. Blank and Brewer identify many of the salient issues. Establishing teaching on empirically-based studies presents problems that may be resolved. However, using specific methodological criteria to define "empirical" will be harmful. Emphasizing student achievement and aligning curricula, instruction, and professional development also presents problems, but these can be resolved, at least in theory. Using traditional norm-referenced tests to drive curricula will ultimately not benefit all children because some children will be left behind.

Those of us interested in science education in general, and particularly in assuring that no child's education leaves ecology behind, have important decisions before us. On one hand, we can continue to critique NCLB. This will keep us busy for at least a decade, because NCLB is rich in opportunities for criticism. On the other hand, we can use the spirit of the legislation as a means of enhancing opportunities for all students to learn more about environmental systems, which would be more productive.

When asked about presidential leadership, Henry Adams replied, "The President resembles the commander of a ship at sea; he must have a helm to grasp, a course to steer, a port to seek" (Adams 1958). There is a reality that we must confront regarding NCLB and ecology education. Ecology does not have a clear position in this legislation and will probably not develop one. However, ecologists can make clear and compelling connections between understanding ecology and complex environmental systems, the presidential challenge of "global economic leadership and security in the 21 st century", and 
the need for contemporary perspectives in curricula.

So what is the "helm to grasp"? First, we should use the National Science Education Standards (NRC 1996), because they include essential ecological concepts in the life science content standards. The standards on "Science in Personal and Social Perspective" also present important content on population growth, resource use, and environmental quality. Together, these two sets of standards present substantial ecological content for $\mathrm{K}-12$ education.

Those interested in ecology education need a clear, coherent, and consistent message about the ecological content of school science programs. Given that the majority of states have used, albeit inconsistently, the national standards in the development of state standards and subsequent state assessments, they represent a point of influence in the educational system

No doubt there are many "courses to steer" for ecology education, each with its own navigational and meteorological problems. We should help school systems and science teachers adapt programs that have the best ecological content available and provide them with the best professional development possible in order to fully and appropriately implement the science program.

Ecologists can play important roles in this process. They can be advocates for including ecology and environmental science in $\mathrm{K}-12$ programs. This may include talking to the school board, writing an editorial for the local newspaper, or visiting the superintendent to let him or her know of their support for the school program and science teachers. They can act as a resource by donating time and effort to the school. As such, ecologists might help design the local standards or formulate the K-12 curricular framework. Finally, they can participate as full partners with the school. In this capacity, they could participate in the analysis and selection of instructional materials, help organize and conduct professional development for the ecological portions of the curriculum, or improve classroom assessments of ecological content.

In one sense NCLB makes the "port to seek" very clear it is student achievement. The present emphasis on assessment has unintentional negative consequences on school improvement. Ecologists and the environmental community should "think nationally, act locally". What can we do to assure that children achieve adequate levels of scientific literacy in general, and ecological literacy in particular? We can help teachers assess students on various dimensions of scientific literacy, such as basic vocabulary and technical terms, major ecological concepts, important procedures of scientific inquiry, and analysis of multidimensional issues (Bybee 1997).

I have tried here to provide the ecological community with a positive and potentially productive response to the NCLB legislation. Like most environmental problems, there is no easy or simple solution. However, those in schools and classrooms will benefit from the knowledge, insights, and contributions of ecologists.

\section{References}

Adams H. 1958. The session, 1869-1870. In: Hochfield GE (Ed). The great secession winter of 1860-61 and other essays. New York: Sagamore Press, NY.

Brown L. 2001. Eco economy: building an economy for the earth. New York, NY: Norton \& Company.

Bybee RW. 1997. Achieving scientific literacy from purposes to practices. Portsmouth, NH: Heinemann.

NCSE (National Council for Science and the Environment). 2003. Education for a secure and sustainable future. Washington, DC: NCSE.

NCSE. 2000. Recommendations for improving the scientific basis for environmental decision making. Washington, DC: NCES.

NRC (National Research Council). 1996. National science education standards. Washington, DC: National Academy Press.

NSB (National Science Board). 2000. Environmental science and engineering for the 21st century. Washington, DC: National Science Foundation.

Wilson EO. 2002. The future of life. New York, NY: Vantage Books. 